\title{
Effect of Sulphur and Zinc Containing Customized Fertilizers on Growth, Yield and Nutrient Uptake of Onion
}

\author{
P.H. Rathod*, R.N. Katkar, R. Vrushali. Bhende S.M. Ghawade, \\ S.R. Lakhe, and V.K. Kharche \\ Department of Soil Science and Agricultural Chemistry, Dr. Panjabrao Deshmukh Krishi \\ Vidyapeeth, Akola 444104 (M.S.), India \\ *Corresponding author
}

\section{Keywords \\ Onion, Customized fertilizer, NPK uptake, micronutrient uptake.}

\section{Article Info}

Accepted:

15 December 2019 Available Online: 20 January 2020

\section{A B S T R A C T}

The present investigation was conducted during rabi 2016-17 to study the effect of sulphur and zinc containing customized fertilizers on yield, quality and nutrient uptake by onion in Inceptisols" at Dr. PDKV, Akola. The experiment was laid out in Randomized Block Design with eleven treatments replicated thrice. The soil of experimental site was Inceptisols. The plant samples were collected, analyzed for content and uptake of major and micronutrients. The results revealed that, the highest onion bulb yield, bulb weight and nutrient uptake were recorded with application of balanced fertilizer dose of NPKS Zn (100:50:50:40:17.50 kg N, $\mathrm{P}_{2} \mathrm{O}_{5}, \mathrm{~K}_{2} \mathrm{O}, \mathrm{S}, \mathrm{Zn}$ ) followed by application of recommended dose through customized fertilizer grade NPKS $\mathrm{Zn}+$ compensation of $\mathrm{N}$ and $\mathrm{K}$ through conventional fertilizer. Among the customized grades recommended dose applied through grade III (12:45:00:05:01) and compensation of $\mathrm{N}$ and $\mathrm{K}$ through conventional source recorded highest onion bulb yield, yield attributes and nutrient uptake by onion. The periodical storage study of onion bulb at $30,60,90$ and 120 days recorded lowest physiological weight loss in treatments recommended dose of NPKS $\mathrm{Zn}$ followed by recommended dose of $\mathrm{P}$ through NPS Zn (compensation of N and K through conventional fertilizers). The balanced application of nutrients $(\mathrm{N}, \mathrm{P}, \mathrm{K}, \mathrm{S}$ and $\mathrm{Zn}$ ) either through conventional or customized fertilizer grades (NPS Zn) found beneficial in enhancing onion bulb yield, yield attributing parameters and improvement in onion bulb storage.

\section{Introduction}

Onion (Allium cepa L.) is known as the "Queen of the kitchen". In world India is second largest country in onion production.
Area under onion cultivationwas11.67 lakh ha with production 202.14 lakh million tonne with productivity 17.32 tones ha.It isrich source of minerals like phosphorus, calcium and sulphur. On an average, 32.9 per cent 
sulphur deficiency has been noticed in Indian soils (Shukla et al., 2016). While in Maharashtra sulphur deficiency recorded to the extent of 27.48 per cent whereas in Vidarbha 25.76 per cent (Katkar et al., 2017). Sulphur not only influence the taste, pungency and medicinal properties of onion and garlic but also impart resistance against pests and diseases. Sulphur is also required for the synthesis of three important amino acids such as cystine (27\% S), cystein (26\% $\mathrm{S})$ and methionine $(21 \% \mathrm{~S})$ besides increasing allyl propyl disulphide alkaloid (43\% S), the principle alkaloids responsible for pungency in onion, respectively (Randle and Bussard, 1993).

The survey of Indian soils revealed that about 39.9 per cent of 2.52 lakh soil samples analyzed were found deficient in available $\mathrm{Zn}$ distributed over 20 states (Shukla alet., 2016). Zinc deficiency in Maharashtra has been reported 37.8 per cent and in Vidarbha region 49 per cent (Katkar et al., 2017). Zinc play active role in plant metabolic process such as nitrogen fixation, enzyme activity and is essential for tryptophan synthesis, which is prerequisite for auxin formation, the amount of auxin decreases with zinc deficiency.

There is wide gap between world and Indian productivity; to overcome this gap, customized fertilizers play a vital role in Indian productivity. Central Fertilizer Committee has included customized fertilizers in the Fertilizer (Control) order 1985 , as a new category of fertilizers that are area/soil/crop specific. Customized fertilizers are multinutrient carriers facilitating the application of the complete range of plant nutrients in right proportion to suit the specific requirements of a crop during its stages of growth. Soil fertility status, climate, and cropping pattern in a region pave the way for the development of customized fertilizer formulations. It optimizes the nutrient use for quality produce, high farm productivity and profitability. Customized fertilizers are ideal, highly water soluble, crop specific fertilizers containing primary, secondary and micro nutrient. Uses of customized fertilizers make application of secondary and micronutrients more easy. Moreover, customized fertilizers are the most convenient for application of secondary and micronutrients. Hence, the present investigation was carried out to study the effect of customized fertilizers on yield and nutrient uptake.

\section{Materials and Methods}

The experiment was initiated during rabi season 2015-16 at Chilli and Vegetable Research Unit, Dr. Panjabrao Deshmukh Krishi Vidyapeeth, Akola.The experiment was laid out in a randomized block design with eleven treatments and three replications. The treatment details are $T_{1}$ - Absolute control (No NPK), $\mathrm{T}_{2}$ - Recommended dose (RD) of NPK $\quad\left(100: 50: 50 \quad \mathrm{~kg} \quad \mathrm{ha}^{-1}\right), \mathrm{T}_{3^{-}} \quad \mathrm{RD}$ of $\operatorname{NPKS}\left(100: 50: 50: 40 \quad \mathrm{~kg} \quad \mathrm{ha}^{-1}\right), \mathrm{T}_{4^{-}} \quad \mathrm{RD}$ of NPKS Zn(100:50:50:40:3.50 $\left.\mathrm{kg} \mathrm{ha}^{-1}\right), \mathrm{T}_{5^{-}} \mathrm{RD}$ of NPK + FYM @ $5 \mathrm{t} \mathrm{ha}^{-1}, \mathrm{~T}_{6^{-}}$RD of P through NPS-1(Compensation $\mathrm{N}$ and $\mathrm{K}$ through conventional fertilizers), $\mathrm{T}_{7-} \mathrm{RD}$ of $\mathrm{P}$ through NPS-2(Compensation $\mathrm{N}$ and $\mathrm{K}$ through conventional fertilizers ), $\mathrm{T}_{8^{-}} \mathrm{RD}$ of $\mathrm{P}$ through NPS $\mathrm{Zn}$ (Compensation $\mathrm{N}$ and $\mathrm{K}$ through conventional fertilizers), $\mathrm{T}_{9^{-}} \mathrm{RD}$ of NPK + Sulphur equivalent to NPS 1 supplied in $\mathrm{T} 6, \mathrm{~T}_{10}-\mathrm{RD}$ of NPK + Sulphur equivalent to NPS 2 supplied in $\mathrm{T} 7, \mathrm{~T}_{11^{-}}$RD of NPK + Sulphur and $\mathrm{Zn}$ equivalent to NPS $\mathrm{Zn}$ supplied in $T_{8}$. The treatment were imposed at the time of transplanting and 50 per cent RD of $\mathrm{N}$ was applied one month after transplanting. The soil of experiment site is Inceptisols.

Randomly five plants from each plot were selected to record the observations. The observation on plant height, number of leaves 
per plant, neck thickness, polar and equatorial bulb diameter, plant weight, fresh weight of bulb, total soluble solids (TSS), dry weight of bulb, dry weight of leaves, dry matter yield and fresh yield were recorded. Plant height was measured with the help of metre scale. Neck thickness and bulb diameter was measured with the help of Vernier callipers after harvesting. Total soluble solids were measured with the help of hand refractometer. The data were obtained subjected to statistical analysis as per the standard procedure (Gomez and Gomez, 1984). The samples of leaves and bulb were collected at harvesting and kept in paper bags and air dried in shade. The samples were kept in hot air oven at $64^{\circ}$ $\mathrm{C}$ till the constant weight. After complete drying the dry matter of bulb and leaves parts were recorded and samples were grinded on steel blade mill.

The bulb and leaves samples $(0.5 \mathrm{~g})$ were digested with $10 \mathrm{ml}$ of di-acid using $\mathrm{HNO}_{3}: \mathrm{HClPO}_{4}$ in 9:4 (Piper, 1966) the acid digest was dissolved in double distilled water after filtration ( Whatman filter paper No. 42) final volume made $50 \mathrm{ml}$. Nitrogen was determined from plant sample by digestion in micro Kjeldahl's method using digestion mixture (1:5:1) consisting of $\mathrm{CuSO}_{4}, \mathrm{~K}_{2} \mathrm{SO}_{4}$ selenium powder and $\mathrm{H}_{2} \mathrm{SO}_{4}$. (Jackson, 1973).The phosphorus content in the plant sample was determined by Vanadomolybdate yellow colour method in nitric acid medium. The intensity of colour was read at $420 \mathrm{~nm}$ wave length using spectrophotometer (Jackson, 1973). Potassium content in the plant sample was estimated by atomizing the diluted plant extract in the Flame Photometer as described by Jackson (1973). Sulphur was estimated from diacid extract turbidimetrically using Spectrophotometer (Chesnin and Yien, 1950). Zn, Fe, Mn and $\mathrm{Cu}$ from the plant sample were estimated from diacid extract usingAtomic Absorption Spectrophotometer (Issac and Kerber, 1971).

\section{Results and Discussion}

\section{Growth Parameter Plant height}

The significantly highest plant height (50.80 $\mathrm{cm})$ was recorded with the application of recommended dose of NPKS Zn which was found at par with treatment of recommended dose of NPKS and recommended dose of fertilizer through customized grade III NPS $\mathrm{Zn}+$ compensation of $\mathrm{N}$ and $\mathrm{K}$ through conventional fertilizers (Table 1).Khan et al.(2007) reported that maximum plant height in the treatment of balanced nutrition applied with nitrogen fertilization, while Pramanik and Tripathy (2017) noticed increased in plant height by application of micronutrients. The increase in plant height with the application of sulphur might be due to its role in the synthesis of chlorophyll. The results are in conformity with the findings reported by Jaggi (2005) and Channagoudra (2004) who also observed increased in $\mathrm{S}$ levels enhanced plant height.

\section{Number of leaves}

The number of leaves per plant in onion were recorded highest (11.43) with application of recommended dose of NPKS Zn followed by recommended dose of $\mathrm{P}$ through customized fertilizer grade III NPS Zn+ compensation of $\mathrm{N}$ and $\mathrm{K}$ through conventional fertilizers and Recommended dose of NPK + Sulphur equivalent to NPS $\mathrm{Zn}$ supplied in $\mathrm{T}_{8}$.

\section{Bulb weight}

The significantly highest bulb weight was observed in recommended dose of NPKS Zn (48.31g) followed by recommended dose of NPKS, recommended dose of $\mathrm{P}$ through NPS $\mathrm{Zn}+$ compensation of $\mathrm{N}$ and $\mathrm{K}$ through conventional fertilizers, Recommended dose of NPK + Sulphur equivalent to NPS Zn supplied in $\mathrm{T}_{8}$. Among customized fertilizer 
grade treatments highest bulb weight was observed in recommended dose of fertilizer through grade III (NPKS Zn) as compared to treatment of grade I and grade II. It indicate that application of N,P,S and Zn fertilizers in balanced quantity has positive effect on weight of onion bulb. The sulphur has a synergetic effect along with other nutrients like nitrogen in increasing bulb weight. The balanced nutrition helped to proper growth and development of onion bulb. Similar findings were reported by Rashid,(2010).

\section{Neck thickness}

The highest neck thickness (1.73) $\mathrm{cm}$ was recorded with recommended dose of NPKS $\mathrm{Zn}$ which was found at par with treatment of recommended dose of NPKS and recommended dose through customized fertilizer grade III NPS Zn (compensation of $\mathrm{N}$ and $\mathrm{K}$ through conventional fertilizers). Among customized fertilizer grades, grade III recorded higher neck thickness.

\section{Diameter of bulb}

The polar diameter and equatorial diameter of bulb were found to be increased with balanced nutrition. The result indicated that the highest polar diameter $(4.60 \mathrm{~cm})$ and equatorial diameter $(6.04 \mathrm{~cm})$ were recorded in the treatment of recommended dose of NPKS $\mathrm{Zn}$ and followed by treatment of recommended dose of NPKS.

The customized fertilizer grade III (NPS Zn) recorded highest bulb diameter. The significant increase in bulb polar and equatorial diameter at higher levels of $S$ application might be due to increase in uptake of nutrients which might have influenced the synthesis and translocation of stored materials. These results are in accordance with findings reported byJaggi (2005), Nandi et al (2002) and Hariyappa (2003).

\section{Yield of onion bulb}

The data indicated that sulphur application of $40 \mathrm{~kg} \mathrm{ha}{ }^{-1}$ along with RDF recorded significantly highest onion bulb yield (397.75 $\mathrm{q} \mathrm{ha} \mathrm{h}^{-1}$ ) with the combined application of recommended dose of NPKS Zn which was found at par with recommended dose NPKS (387.79 q $\mathrm{ha}^{-1}$ ) and recommended dose through customized fertilizer grade III (12:45:00:05:01) through NPS $\mathrm{Zn}+$ compensation of $\mathrm{N}$ and $\mathrm{K}$ through conventional fertilizers $\left(382.80 \mathrm{q} \quad \mathrm{ha}^{-1}\right)$ (Table.2). The bulb yield was increased with successive increase in the levels of sulphur up to $40 \mathrm{~kg} \mathrm{ha}^{-1}$.

The similar trend was found in leaves yield. Pradhan et al (2015) also reported the increase in bulb yield with increase in sulphur levels and Singh et al.(1995) reported that bentonite sulphur was found more efficient in increasing yield and uptake of nutrients than gypsum. This yield increase was noticed due to the increase in bulb size and weight. The results suggest that sulphur deficiency has adverse effect on the growth and yield of onion.The resultsare in agreementwith findings on sulphur fertilisation reported by Nasreen et al., (2007).Among the customized fertilizer grades, the RDF through grade III (12:45:00:05:01) recorded significantly highest onion bulb yield (397.75 $\mathrm{q} \mathrm{ha}^{-1}$ ) as compared to the nutrients applied through grade I (19:38:00:07) and grade II (12:46:00:07). Kamble and Kathmale (2015) also reported that RDF through customized fertilizer to onion recorded highest onion bulb yield and yield contributing character.

The increase in bulb yield with application of sulphur and zinc along with RDF might be due to increased in uptake of N, P, K, S and micronutrients $\mathrm{Zn}, \mathrm{Cu}, \mathrm{Fe}$ and $\mathrm{Mn}$ by the crop. This helped to enhance the synthesis and translocation of photosynthates to the 
bulbs and the storage organs of the onion. Similar results were also reported in onion by Sankaran et al., (2005) and Jaggi (2005) reported who significantly higher bulb yield of onion with application of $30 \mathrm{~kg} \mathrm{~S}$ per ha.
Pradhan et al., (2015) also noticed that application of S @ 30 or $45 \mathrm{~kg}$ ha in the form of gypsum not only increased the bulb yield of onion but also higher uptake of nutrients.

Table.1 Effect of sulphur and zinc containing customized fertilizers on growth and yield attributes of onion

\begin{tabular}{|c|c|c|c|c|c|c|c|}
\hline \multirow{2}{*}{\multicolumn{2}{|c|}{ Treatments }} & \multirow{3}{*}{$\begin{array}{c}\begin{array}{c}\text { Plant } \\
\text { height } \\
(\mathbf{c m})\end{array} \\
42.27\end{array}$} & \multirow{3}{*}{\begin{tabular}{|c|}
$\begin{array}{l}\text { No. of } \\
\text { leaves } \\
\text { plant }^{-1}\end{array}$ \\
8.47
\end{tabular}} & \multirow{3}{*}{$\begin{array}{c}\begin{array}{c}\text { Bulb } \\
\text { weight } \\
\text { (g bulb- } \\
\text { 1) }\end{array} \\
31.44\end{array}$} & \multirow{3}{*}{$\begin{array}{c}\begin{array}{c}\text { Neck } \\
\text { thickness } \\
(\mathbf{c m})\end{array} \\
1.32\end{array}$} & \multirow{2}{*}{\multicolumn{2}{|c|}{ Bulb diameter $(\mathrm{cm})$}} \\
\hline & & & & & & & \\
\hline $\mathbf{T}_{1}$ & Absolute Control & & & & & $\begin{array}{c}\text { Vertica } \\
\mathbf{l} \\
3.93\end{array}$ & $\begin{array}{c}\text { Horizontal } \\
4.95\end{array}$ \\
\hline $\mathbf{T}_{2}$ & RDF of NPK & 43.07 & 8.93 & 40.86 & 1.38 & 4.08 & 5.15 \\
\hline $\mathbf{T}_{3}$ & RDF of NPKS & 48.90 & 9.67 & 47.10 & 1.60 & 4.54 & 5.83 \\
\hline $\mathbf{T}_{4}$ & RDF of NPKS Zn & 50.80 & 11.43 & 48.31 & 1.73 & 4.60 & 6.04 \\
\hline $\mathbf{T}_{\mathbf{5}}$ & RDF of NPK + FYM & 48.10 & 9.10 & 45.69 & 1.57 & 4.47 & 5.51 \\
\hline $\mathbf{T}_{6}$ & $\begin{array}{l}\text { RDF of P through NPS-1( N } \\
\text { and K through conventional } \\
\text { fertilizers) }\end{array}$ & 46.67 & 9.93 & 46.28 & 1.51 & 4.25 & 5.40 \\
\hline $\mathbf{T}_{7}$ & $\begin{array}{l}\text { RDF of P through NPS-2( N } \\
\text { and K through conventional } \\
\text { fertilizers) }\end{array}$ & 45.70 & 10.27 & 46.05 & 1.45 & 4.21 & 5.48 \\
\hline $\mathbf{T}_{8}$ & $\begin{array}{l}\text { RDF of } \mathrm{P} \text { through NPS } \mathrm{Zn}(\mathrm{N} \\
\text { and K through conventional } \\
\text { fertilizers) }\end{array}$ & 49.40 & 11.10 & 46.49 & 1.58 & 4.52 & 5.67 \\
\hline $\mathbf{T}_{9}$ & $\begin{array}{l}\text { RDF of NPK }+ \text { Sulphur } \\
\text { equivalent to NPS } 1 \text { supplied in } \\
T_{6}\end{array}$ & 47.60 & 10.53 & 45.91 & 1.40 & 4.13 & 5.16 \\
\hline $\begin{array}{l}\mathbf{T}_{1} \\
0\end{array}$ & $\begin{array}{l}\text { RDF of NPK }+ \text { Sulphur } \\
\text { equivalent to NPS } 2 \text { supplied in } \\
T_{7}\end{array}$ & 46.40 & 9.17 & 45.53 & 1.55 & 4.07 & 5.48 \\
\hline \multirow[t]{3}{*}{$\begin{array}{l}\mathbf{T}_{1} \\
1\end{array}$} & $\begin{array}{l}\text { RDF of NPK }+ \text { Sulphur and Zn } \\
\text { equivalent to NPS Zn supplied } \\
\text { in } T_{8}\end{array}$ & 48.27 & 10.40 & 46.16 & 1.57 & 4.42 & 5.55 \\
\hline & $\mathrm{SE}(\mathbf{m}) \pm$ & 1.20 & 0.42 & 2.07 & 0.05 & 0.12 & 0.20 \\
\hline & CD at $5 \%$ & 3.54 & 1.22 & 6.11 & 0.16 & 0.35 & 0.58 \\
\hline
\end{tabular}


Table.2 Effect of sulphur and zinc containing customized fertilizers on onion bulb and leaves yield

\begin{tabular}{|c|c|c|c|}
\hline & \multirow[t]{2}{*}{ Treatments } & \multicolumn{2}{|c|}{ Yield $\left(\mathbf{q} \mathbf{h a}^{-1}\right)$} \\
\hline & & Bulb & Leaves \\
\hline $\mathbf{T}_{1}$ & Absolute Control & 258.86 & 20.71 \\
\hline $\mathbf{T}_{2}$ & RDF of NPK & 316.39 & 23.55 \\
\hline $\mathbf{T}_{\mathbf{3}}$ & RDF of NPKS & 387.79 & 27.15 \\
\hline $\mathbf{T}_{4}$ & RDF of NPKS Zn & 397.75 & 27.84 \\
\hline $\mathbf{T}_{\mathbf{5}}$ & RDF of NPK + FYM & 383.28 & 26.03 \\
\hline $\mathbf{T}_{6}$ & $\begin{array}{l}\text { RDF of P through NPS-1( } \mathrm{N} \text { and } \mathrm{K} \\
\text { through conventional fertilizers) }\end{array}$ & 381.04 & 26.67 \\
\hline $\mathbf{T}_{7}$ & $\begin{array}{l}\text { RDF of P through NPS- } 2 \text { ( N and K } \\
\text { through conventional fertilizers) }\end{array}$ & 379.15 & 26.54 \\
\hline $\mathbf{T}_{\mathbf{8}}$ & $\begin{array}{l}\text { RDF of } \mathrm{P} \text { through NPS } \mathrm{Zn}(\mathrm{N} \text { and } \mathrm{K} \\
\text { through conventional fertilizers) }\end{array}$ & 382.80 & 26.80 \\
\hline $\mathbf{T}_{9}$ & $\begin{array}{l}\text { RDF of NPK }+ \text { Sulphur equivalent to } \\
\text { NPS } 1 \text { supplied in } T_{6}\end{array}$ & 377.96 & 26.46 \\
\hline $\mathbf{T}_{10}$ & $\begin{array}{l}\text { RDF of NPK }+ \text { Sulphur equivalent to } \\
\text { NPS } 2 \text { supplied in } T_{7}\end{array}$ & 374.84 & 26.24 \\
\hline \multirow[t]{3}{*}{$\mathbf{T}_{11}$} & $\begin{array}{l}\text { RDF of NPK }+ \text { Sulphur and } \mathrm{Zn} \\
\text { equivalent to NPS Zn supplied in } \mathrm{T}_{8}\end{array}$ & 380.02 & 26.60 \\
\hline & $\mathrm{SE}(\mathrm{m}) \pm$ & 15.20 & 1.20 \\
\hline & $\mathrm{CD}$ at $5 \%$ & 44.82 & 3.53 \\
\hline
\end{tabular}


Table.3 Total uptake of nutrients by onion as influenced by various treatments

\begin{tabular}{|c|c|c|c|c|c|c|c|c|}
\hline \multirow[t]{2}{*}{ Treatments } & \multicolumn{4}{|c|}{$\begin{array}{l}\text { Total uptake of major nutrients } \\
\left(\text { kgha }^{-1}\right)\end{array}$} & \multicolumn{4}{|c|}{$\begin{array}{l}\text { Total uptake of micro nutrients } \\
\qquad\left(\mathrm{g} \mathrm{ha}^{-1}\right)\end{array}$} \\
\hline & $\mathrm{N}$ & $\mathrm{P}$ & $\mathrm{K}$ & $S$ & $\mathrm{Zn}$ & $\mathrm{Fe}$ & $\mathrm{Cu}$ & $\mathrm{Mn}$ \\
\hline$T_{1}$ & 88.88 & 13.01 & 72.33 & 14.05 & 713.48 & 990.5 & 55.4 & 177.2 \\
\hline $\mathbf{T}_{2}$ & 113.29 & 19.44 & 94.91 & 19.44 & 931.44 & 1257.1 & 72.1 & 239.9 \\
\hline $\mathbf{T}_{3}$ & 132.67 & 24.51 & 111.10 & 31.92 & 1256.90 & 1468.9 & 85.9 & 287.9 \\
\hline $\mathbf{T}_{4}$ & 137.67 & 26.54 & 116.39 & 33.84 & 1395.47 & 1523.7 & 90.1 & 302.1 \\
\hline $\mathbf{T}_{5}$ & 123.90 & 22.49 & 105.09 & 28.25 & 1164.16 & 1437.0 & 85.0 & 294.9 \\
\hline $\mathbf{T}_{6}$ & 126.44 & 23.56 & 107.88 & 30.06 & 1131.98 & 1402.8 & 82.0 & 284.3 \\
\hline $\mathbf{T}_{7}$ & 128.37 & 22.73 & 107.65 & 29.79 & 1137.61 & 1434.0 & 83.4 & 287.2 \\
\hline $\mathbf{T}_{8}$ & 130.30 & 24.25 & 109.90 & 31.77 & 1214.68 & 1461.6 & 86.8 & 292.5 \\
\hline $\mathbf{T}_{9}$ & 123.02 & 22.47 & 102.61 & 28.21 & 1100.68 & 1376.6 & 81.5 & 273.2 \\
\hline$T_{10}$ & 121.91 & 21.10 & 102.50 & 28.73 & 1072.17 & 1354.8 & 79.7 & 271.7 \\
\hline$T_{11}$ & 129.38 & 23.40 & 108.22 & 31.36 & 1194.58 & 1452.4 & 84.0 & 286.9 \\
\hline SE (m) \pm & 3.35 & 0.93 & 3.13 & 1.36 & 43.16 & 103.9 & 3.29 & 28.35 \\
\hline CD at $5 \%$ & 9.87 & 2.73 & 9.24 & 4.00 & 127.30 & 306.6 & 9.70 & 85.05 \\
\hline
\end{tabular}

Total uptake of nutrients

The total uptake of N,P,K, S and $\mathrm{Zn}, \mathrm{Cu}, \mathrm{Fe}$, Mn nutrients observed significantly highest with application of $\mathrm{S}$ and $\mathrm{Zn}$ along with recommended dose of NPKwhich was found at par with recommended dose of NPKS , recommended dose of $\mathrm{P}$ through NPS $\mathrm{Zn}+$ compensation of $\mathrm{N}$ and $\mathrm{K}$ through conventional fertilizers and recommended dose of $\mathrm{P}$ through NPS-2 + compensation of $\mathrm{N}$ and $\mathrm{K}$ throughconventional fertilizers (Table 3). Among the customized fertilizer grades, the application of nutrient through grade III (NPS Zn) recorded higher uptake of nutrients found at par with the RDF through grades I and II. These findings corroborate with the results reported by Singh and Pandey (2006).Pallavi et al., (2015) reported higher uptake of nutrients with increased levels of sulphur through different sources.

\section{Conclusion}

It can be concluded that, the highest onion bulb yield, bulb weight and nutrient uptake were registered with the application of balanced fertilizer dose of NPKS $\mathrm{Zn}$ (100:50:50:40:17.50 kg N, $\mathrm{P}_{2} \mathrm{O}_{5}, \mathrm{~K}_{2} \mathrm{O}, \mathrm{S}, \mathrm{Zn}$ ) followed by application of recommended dose through customized fertilizer grade NPKS Zn (12:45:00:05:01) + compensation of $\mathrm{N}$ and $\mathrm{K}$ through conventional fertilizers.

\section{Literature cited}

Acharya, U., K. Venkatesan, T. Saraswathi and K.S. Subramanian (2015). Effect of zinc and boron application on growth and yield parameters of multiplier onion 
(Allium cepa 1. Var aggregatum don.) var. co (on) 5. Inter. J. of Res. Vol-2: 755-765.

Channagoudra, R. F. 2004. Response of onion (Allium cepa L.) to irrigation schedule and sulphur levels in northern transitional zone of Karnataka. M.Sc. (Ag.) Thesis, University of Agricultural Sciences, Dharwad.

Chesnin, L. and C.H. Yien. 1950. Turbidimetric determination of available sulphur. Soil Sci. Soc. Am. Proc. 15: 149-151.

Hariyappa, N. 2003. Effect of potassium and sulphur on growth, yield and quality parameters of onion (Allium cepa L.). M. Sc. (Ag.) Thesis, University of Agricultural Sciences, Dharwad.

Issac, R.A. and J.D. Kerber, 1971. Atomic absorption and flame photometry: Technique and uses in soil, plant and water analysis. In Walsh, L.M. (ed). Instrumental Method of Soils and plant Tissue. Soil. Sci. Soc. Am. Madison, Wisconsin: 18-37.

Jackson, M.L., 1973. Soil Chemical Analysis

(Edn. 2) Prentice Hall of India Pvt Ltd New Delhi. 69-182.

Jaggi, R. C. 2005. Sulphur levels and sources affecting yield and yield attributes in onion (Allium cepa). Indian J. Agric. Sci., 75: 154 -56. Kumar, A. and Singh, O.1992. Dry matter accumulation in sulphur deficient onion plants. Indian J. Agric. Res. 26: 107-09.

Katkar, R.N.,V.K. Kharche, S.R. Lakhe, P.R. Deshmukh, A.B. Shukla, Pankaj Tivari, A.B. Aage, A.D. Kadlag, 2017. Geographical information system based Micro and Secondary nutrient in soils Maharashtra. Dr. P.D.K.V. Akola. Bulletin No. 491: 10.

Khan AA, M. Zubair, A. Bari and F. Maula, 2007. Response of onion (Allium cepa) growth and yield to different levels of nitrogen and zinc in swat valley. Sarhad
J. of Agri, 23(4).

Nandi, R. K., M. Deb, T. K. Maity and G. Sounda, 2002. Response of onion to different levels of irrigation and fertilizer. Crop Res., 23 : 317 - 20.

Nasreen, Shamima., M.M.,Haque, M.A., Hossain and A.T.M.,Farid, 2007. Nutrient uptake and yield of onion as influenced by nitrogen and sulphur fertilization. Bangladesh J. of Agri. Res. 32(3): 413-420.

Pallavi Ghotekar, Katkar, R.N., Kharche, V.K., Laharia, G.S., Ghawade, S.M. and Lakhe, S.R. 2015. Effect of sources and levels of sulphur on yield and quality of onion and soil fertility status. Journal of Agriculture Research and Technology, 40 (1): 163-166.

Piper, C.S., 1966. Soil and Plant Analysis. Asian Reprint, Hans Publication Bombay, India.

Pradhan, R., Pattnaik, A. K., Tripathy, P., Mallikarjunarao, K., Sahoo, B. B. and Lenka, J. 2015. Influence of sulphur fertilization on nutrient uptake of onion (Allium cepa L.). J. Crop Weed, 11:13438

Randle, W. M. and Bussard, M. L.1993. Pungency and sugars of short day onion as affected by sulphur nutrition. J. Amer. Soc. Hort. Sci. 118: 766-70.

Rashid, M. H. A. 2010. Effect of sulphur and GA3 on the growth and yield of onion. Progress. Agric. 21(1 \& 2): 57 - 63.

Sankaran, K., Bharathi, C. and Sujatha, S. 2005. Effect of sulphur fertilization on yield and nutrient uptake by onion in red soil (Uodic Haplustalf). J. Maharastra Agril. Univ., 30 :135 -36.

Shukla, A.K., Pankaj Tiwari, Saheb Sidhiqqui, Ashok K. Patra and S.K. Choudhary, 2016. Micro and secondary nutrients is Indian soils, condition of deficiency, prevention and recommendations. Indian Institute Soil Science Bhopal. 3: 25. 
Singh Vinay and M. Pandey, 2006. Effect of integrated nutrient management on yield of and nutrient uptake by onion and on soil fertility. J. Indian Soc. Soil Sci. 54(3): 365-367.
Singh, L., S. R. Bhonde and V. K. Mishra, 1995. Effect of different organic manures and inorganic fertilizers on yield and quality of rabi onion. NHRDF Newsletter. 17(3): 1-3.

\section{How to cite this article:}

Rathod P.H., R.N. Katkar, R. Vrushali. Bhende S.M. Ghawade, S.R. Lakhe, and Kharche. V.K. 2020. Effect of Sulphur and Zinc Containing Customized Fertilizers on Growth, Yield and Nutrient Uptake of Onion. Int.J.Curr.Microbiol.App.Sci. 9(01): 2061-2069

doi: https://doi.org/10.20546/ijcmas.2020.901.234 